University of Michigan Law School

University of Michigan Law School Scholarship Repository

Articles

Faculty Scholarship

1911

\title{
The Standard Oil Decision: The Rule of Reason
}

Horace LaFayette Wilgus

University of Michigan Law School

Available at: https://repository.law.umich.edu/articles/925

Follow this and additional works at: https://repository.law.umich.edu/articles

Part of the Antitrust and Trade Regulation Commons, Business Organizations Law Commons, Courts Commons, Legislation Commons, and the Supreme Court of the United States Commons

\section{Recommended Citation}

Wilgus, Horace LaFayette. "The Standard Oil Decision: The Rule of Reason." Mich. L. Rev. 9 (1911): 643-70.

This Article is brought to you for free and open access by the Faculty Scholarship at University of Michigan Law School Scholarship Repository. It has been accepted for inclusion in Articles by an authorized administrator of University of Michigan Law School Scholarship Repository. For more information, please contact mlaw.repository@umich.edu. 


\title{
MICHIGAN
}

\section{LAW REVIEW}

$\begin{array}{lll}\text { VOI. IX. } & \text { JUNE, IgII No. } 8\end{array}$

\section{THE STANDARD OIL DECISION ; THE RULE OF REASON.}

\begin{abstract}
A
FTER twenty-one years the Sherman Anti Trust Act has been applied to the typical combination restraining interstate commerce, which that act was designed to prevent.

In, the debate in the United States Senate, on the original bill introduced by Senator Sherman, he said : ${ }^{1}$

"Associated enterprise and capital are not satisfied with partnerships and corporations competing with each other, and have invented a new form of combination, commonly called trusts, that seeks to avoid competition by combining the controlling corporations, partnerships, and individuals engaged in the same business, and placing the power and property of the combination under the government of a few individuals, and often under the control of a single man called a trustee, a chairman or a president. The sole object of , such a combination is to make competition impossible. It can control the market, raise or lower prices, as will best promote its selfish interests, reduce prices in a particular. locality and break down competition and advance prices at will where competition does rot exist. Its governing motive is to increase the profits of the parties comprising it. The law of selfishness, uncontrolled by competition, compels it to disregard the interests of the consumer. It dictates terms to transportation companies, it commands the price of labor without fear of strikes, for in its field it allows no competitors. Such a combination is far more dangerous than any heretofore invented, and, when it embraces the great body of all the corporations engaged in a particular industry in all of the states of the Union, it tends to advance the priçe to the consumer
\end{abstract}

I See Congressional Record, Vol. 21, Ma1..21, 1890; Bills and Debates in Congress relating to trusts, $1888-1902$, pp. 95-6. There are many other references to the Standard Oil Co. in the debates: Allison, p. 126; Teller, p. 170; Wilson, p. 337. 
of any article produced, it is a substantial monopoly injurious to the public, and, by the rule of both the common and the civil law, is null and void and the just subject of restraint by the courts, of forfeiture of corporate rights and privileges, and in some cases should be denounced as a crime, and the individuals engaged in it should be punished as criminals. It is this kind of a combination we have to deal with now."

"Do I exaggerate the evil we have to deal with? I do not think so. I do not wish to single out any particular trust or combination. It is not a particular trust, but the system I aim at. I will only cite a very few instances of combinations that have been. the subject of judicial or legislative inquiry, to show what has been and what can be done by them," as follows:

In Handy v. C. \& M.R.R. Co., 3 I Fed. 689, 693. "The Standard Oil Co. and George Rice were competitors in the business of refining oil; the Standard desired to crush Rice and his business, and under threat of building a pipe line, compelled the receiver of the railroad to carry its oil at ro cents per barrel and charge Rice 35 cents per barrel for a like service, and pay the Standard 25 cents out of the 35 cents thus exacted from Rice."

"It also appears" in an equity suit in Pennsylvania v. Penn. $R . R$. (I879), "by testimony of A. J. Cassatt, that the Standard Oil Company were receiving rebates of $49 \mathrm{c}$ per bbl. on crude oil from Brad- ford Oil region to tide water, $5 \mathrm{I} / 2 \mathrm{c}$ from the lower oil region to tide water, and $64 \% 2 \mathrm{c}$ from Cleveland to tide water,"-or "the annual illegal receipts by the Standard Oil Co. would have been $\$ 5,480,000$. ." "I do not wish to single out the Standard Oil Company. *** I only refer to them -because they are the oldest of these combinations founded upon contracts which have been copied by the other corporations." "Sir, now the people of the United States as well as of other countries are feeling the power and grasp of these combinations, and are demanding of every legislature and of Congress a remedy for this evil, only grown into huge proportions in recent times. They had monopolies and mortmains of old, but never before such giants as in our day. You must heed their appeal or be ready for the Socialist, the Communist, and the Nihilist. Society is now disturbed by forces never felt before."3

The Supreme Court of the United States has now-after these 2I years,-decided ${ }^{4}$ that the Standard Oil Company of New Jersey, is an unlawful combination in restraint of interstate and foreign commerce, in violation of the Federal Sherman Anti-Trust Act of

\footnotetext{
2 Ib. Mar. 24, 1890; Bills \& Debates, p. 167.

3 Ib. Bills \& Debates, p. Ior.

United States v. Standard Oil Co., - U. S. -, (May 15, 1911).
} 
I89o. The court's decision to this effect is unanimous, affirming the unanimous decision of the Circuit Court.5

The court ruled: (I) That the Anti-Trust Act makes only contracts and combinations in unreasonable restraint of interstate and foreign trade and commerce illegal, and (2) that the Standard Oil Co. of New Jersey is such a combination. Chief Justice White writes the opinion, Mr. Justice HARIAN vigorously dissenting on the first proposition. Whether all the other justices concur in the result only, or also upon the first proposition, is not definitely stated in the reports received; but that a majority of the court concurs on the first proposition is indicated by the words of the Chief Justice that if there are statements in former decisions inconsistent with this, "they are necessarily now limited and qualified."

The Court had no difficulty in unanimously finding from the facts, that the Standard Oil Company of New Jersey was a combination in unreasonable restraint of interstate commerce. The Circuit Court also had no difficulty in so unanimously finding. Hence, there was no question before the court requiring it to decide that the Antitrust Act applied only to combinations in unreasonable restraint of interstate commerce, and it seems unusual for the court in a case where such a question is not involved to overrule two prior decisions where such a question was directly and necessarily involved and passed upon.

The facts are generally known and voluminous (23 volumes, I2000 pages), yet a summary is proper to show how unnecessary it was for the court in this case to announce the first proposition. The following, gleaned from various sources, but more than confirmed by the record in the case, will make this clear:

Oil was "struck" by boring in 1858, in Northwestern Pennsylvania, near Titusville, about 25 miles from Corry, Union City, and Meadville, I25 miles from Cleveland, and I70 from Pittsburg by rail. The Pennsylvania road reached Corry and Union City, and from the latter connected with the Lake Shore, 25 miles away, at Erie; the Erie road ran through Corry, Union City and Meadville. In 1863 the Oil Creek railroad reached Titusville and Oil City from Corry, and the Erie road built to Franklin; in 1868 the Lake Shore, completed a line to Oil City. By I868 successful pipe lines; storage reservoirs, and transferable oil certificates were in use. The first refinery had been built in $\mathrm{I} 862$, in which the processes yet in use were employed. In $1865 \mathrm{Mr}$. J. D. Rockefeller went into the refining business at Cleveland. In I867 he took in his brother William and H. M. Flagler. In I 868 Mr. Rockefeller represented to General

\footnotetext{
573 Fed. 177; 152 Fed. 290.
} 
Devereux, Vice-President. of the Lake Shore. road, that building refineries at the oil regions would ruin the Cleveland refineries, and destroy the oil traffic of the road; a rebate of $I_{5}$ cents per barrel from the 40 cent rate on the crucle oil from the fields was made to $\mathrm{Mr}$. Rockefeller, and he agreed to fight. it out with the oil region refineries. ${ }^{6}$ In 1870 , the Standard Oil Co. of Ohio was formed by Mr. Rockefeller and his associates with a capital stock of $\$ I, 000,000$, and their refining capacity was 600 barrels of crude oil daily ${ }^{2}$-the production of all the I50 refineries of the country being 15,000 barrels daily. ${ }^{8}$ Some of the railroad officials became stockholders in the Standard Oil Co. ${ }^{\circ}$ In I87I (May 6) the South Improvement Co. was chartered in Pennsylvania, with very broad powers; this was. brought to Mr. Rockefeller's attention as early as. October, $187 \mathrm{I},{ }^{10}$ and he, and four other Standard Oil Co. members, took 1,375 shares of the 2,000 of its stock, and Peter Watson, freight agent of the Lake Shore, took Ioo more. ${ }^{11}$ The company was organized, Watson made president, and January 18 , I872, a contract was entered into with the railroads, signed by the presidents or managers, whereby oil rates were to be doubled, and the South Improvement Co. was to have rebates ( 40 cents out of 80 cents on crude oil to Cleveland, $\$ 1.06$ out of $\$ 2.56$ to New York) on crude oil shipped by it, and 50 cents out of $\$ 2.00$ on refined, from Cleveland to New York; and in addition to these rebates; the South Improvement Co. was to have drawbacks to the same amount on all oil shipped by all.other shippers; the rate from the oil fields to New York, I25 miles nearer than Cleveland, was made $\$ 2.92$ - or 92 cents higher; the railroads agreed to furnish all way bills of all oil shipped by any one and open their books to them (the Improvement Co.) and do everything they. could to insure them. "against loss or injury by competition." February I2 the Standard increased its stock to $\$ 2,500,000$, and Mr. Rockefeller proceeded to Cleveland, and told the thirty refineries there that if they didn't sell their property to him it would be valueless-that there was a combination of railroad and oil men. ${ }^{12}$. The result was that of the thirty refineries all but four or five sold out at from 45 to 65 per cent of their value. ${ }^{13}$ The premature putting into

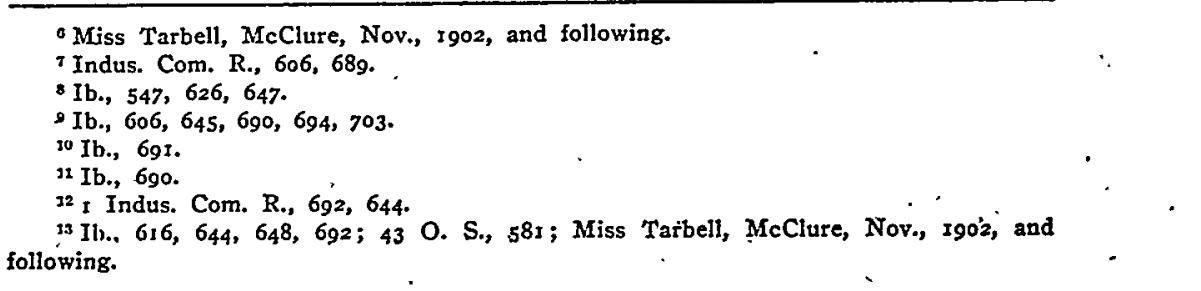


effect of this contract, February 26 , almost led to riots ${ }^{14}$ in the oil regions, and the railroads were obliged to abrogate it, and there followed legislative investigations and the repeal of the charter, March 25, I872. A new contract was made with "perfect equality to all shippers," which didn't last two weeks, and it soon became apparent that the railroads."were doing for the-Standard secretly just what they had publicly contracted to do for the South Improvement Co."15 The details are obscure in some places. The result, however, was perfectly apparent. The Standard first acquired control of the local pipe lines, by means of drawbucks of 22 cents per barrel allowed to the Standard lines-and the other local lines "died off like sheep."16 In 1875 , lower rates were given the Standard on western shipments, by allowing them to ship tank cars averaging Ioo barrels and billing them at 80 ,barrels, and, although the tariff rates were charged, "according to some prearranged method," a portion was refunded under the names of "drawbacks" or "rebates."17 This contract lasted

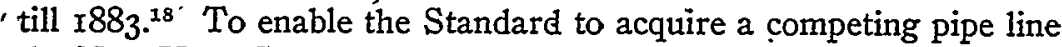
the New York Central made a rate netting II cents to the Standard, when the open rate was $\$ 1.90$ from Cleveland to New York. ${ }^{19}$ In 1878 , the Standard, stating they had regularly received 35 cents commission per barrel from the New York Central, and 20 cents from the Erie, demanded 20 cents per barrel from the Pennsylvania on all oil shipped by these roads, and Mr. Cassatt granted it "after seeing the receipted bills" from the other roads. This amounted on the Pennsylvania alone, in two months, to $\$ 68,753$. It had been in existence since October 17,1877 , on the other roads. ${ }^{20}$ Another contract gave a Standard Oil Terminal Company $221 / 2$ cents "on all oil transported" by the Pennsylvania Co. ${ }^{21}$ In these ways, by 1879 , the Standard had obtained not, only $\cdot$ control of the local pipe lines, but also the terminal facilities of the four trunk lines at Philadelphia, Baltimore and New York; ${ }^{22}$ and had obtained control of 90 or 95 per cent of the refining business of the country, ${ }^{23}$ and, according to the Hepbirn Committee, "the parties who have been driven to the wall have had ample capital and equal ability in the prosecution

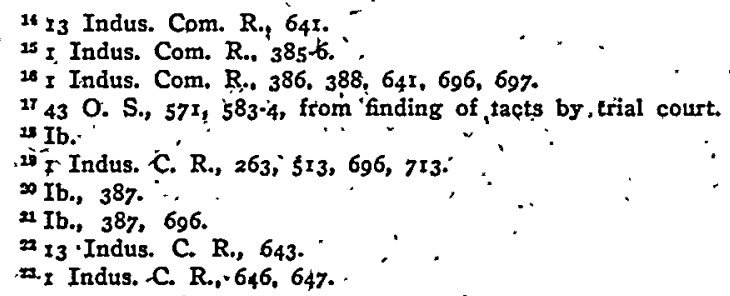


of their business in all things save their ability to acquire facilities for transportation." 24

Sinilar discriminations by railroad companies in favor of the Standard Oil Co., or of some of its numerous affiliated companies had practically continued to the time of bringing the suit in this case. In 1879 , a secret trust agreement was entered into by the 37 stockholders of the Standard Oil Company of Ohio, whereby the stocks of 30 separate competing companies, were turned over to trustees to hold control and manage for the benefit of the stockholders of the Standard. This was superseded in I 882 by the Staridard Oil Trust composed of trustees. Forty corporations (including those of 1879 ) were taken in, their $\$ 56,000,000$ of capital stock be-

- ing exchanged by their stockholders with the trustees for $\$ 70,000,000$ trust certificates. In the ten years after 1882 , the stocks of 78 more companies were acquired, but 50 refineries had been dismantled in the meantime; $\$ 12,000,000$ more trust certificates had been issued for these properties and $\$ 15,000,000$ more issued as a stock dividend, making $\$ 97,250,000$ trust certificates outstanding against property valued at $\$ 67,936,000$. In March, I892, the Supreme Court of Ohio declared the Trust illegal and ordered its dissolution." ${ }^{-\bar{\sigma}}$ At this time the stocks of 84 companies were held by the trustees. The trustees of the trust appointed themselves liquidating trustees and proceeded to liquidate in the following way: The stock of 23 of these companies was transferred to the Standard Oil Co. of New Jersey; that of I I other companies to the Standard Oil Co. of New -York; that of Ir other companies to the Anglo-American Oil Co. of Englarid; and that of 19 other companies to 7 other corporations, leaving the stock of 20 other companies in the hands of the trustees for distribution; and these 20 companies by stock ownership controlled all of the others which had been in the hands of the trustees; since there were 972500 trust certificates of $\$$ roo each the trustees offered to each holder of one trust certificate $\mathrm{I} / 972500$ of the stock of all the 20 companies that owned the stocks of the other 64 companies; by the end of the year 4946I9 trust certificates (a bare majority of all) had been exchanged by the trustees with themselves and their immediate associates, for their proportional amounts of the stocks in the 20 companies thereby giving them the control of these companies, and besides leaving the balance of the trust certificates in their hands. During the next, 6 years only two more shares of trust certificates were exchanged; in the meantime dividends were regularly declared upon the outstanding trust certifi-

2419 Indus. C. R., 654 .

$\approx$ State v. Standard Oil Co., 49 Ohio St. I37. 
cates, and exactly enough to pay these was collected by the trustees from the income of the sub-companies. In . 1897 , the Attorney General of Ohio filed contempt proceedings against the Stanclard Oil Co., for not in good faith dissolving the trust, but on the testimony of MIr. Rockefeller and other high officials of the company, that this had been done in good faith and that the 20 companies were competing, this case was clismissed. However, within a month after filing the suit a large amount of trust certificates was turned in and stock of the sub-companies issued; and in I899 the Stanclard Oil Company of New Jersey was reorganized, with a capital stock of $\$ 100,000,000$, with the power to clo all the kinds of business done by all the sub-companies, with the same by-laws as those of the trust, and with the liquiclating trustees as clirectors; the balance of the trust certificates were liquiclated at once; all of the shares of the 2o sub-companies were then turned over by the shareholders (several thousand in number), to the Standard Oil Company of New Jersey, and exactly 972500 shares of its stock were issued to stich shareholders, and thereby when the Government brought its suit the Stanclard Oil Company of New Jersey oiwned clirectly the stock of 65 sub-companies, which in turn owned the stock of 49 others; and of the 972500 shares of the Standlard Oil Co. of New Jersey, the liquidating trustees and their immediate business associates, own over 500,000 shares; the par value of the shares is $\$ 100$; the market value at the time of the clecision was $\$ 672$, and has been as high as $\$ 843$; and for many years dividencls from 30 to 48 per cent have been paid.

Upon the first proposition,- - that the anti-trust act applies only to contracts and combinations in unreasonable restraint of trade, the Chief Justice insists that "contracts in restraint of tradc," in the statute means only such as were by the common law in unrcasonablc restraint of trade, as known and understood at the time the law was passed. In so holding he reiterates substantially what he said in his dissenting opinion in United Statcs v. Freight Association. ${ }^{20}$

This was the suit brought by the Government to dissolve the Trans-Missouri Freight Association, organized for the purpose of "maintaining just and reasonable rates, preventing unjust discriminations, by furnishing adequate and equal facilities for the interchange of traffic between the several lines, without preventing or illegally limiting competition." The case was heard on the pleadings, and the answer stating the above facts was admitted to be true. The district court, RinkR, J., held that such an agreement did

20166 U. S. 335 . 
not violate the Anti-trust Act. ${ }^{27}$ This was affirmed by the Circuit Court of Appeals, Sanborí and Thayer, JJ., Shiras, J., dissenting. ${ }^{28}$

In the Supreme Court, Mr. Justice Pecknam (White, FinLD, GraY, SHIRAS, JJ., disșenting), delivered the opinion, and said: "What is the meaning of the language as used in the Statute, that 'every contract, combination in the form of trust or otherwise, or conspiracy in restraint of trade or commerce among the sevèral states or with foreign nations, is hereby deciared to be illegall?' Is it confined to a contract or combination which is only in unreasonable restraint of trade or commerce, or does it include what the language of the act plainly and in terms covers, all contracts of that nature. * * * It is now with much amplification of argument urged that the statute, in declaring illegal every combination in the form of trust or otherwise, or conspiracy in restraint of trade or commerce, does not mean what the language used therein plainly imports; but that it only means. to declare illegal any such contract which is in unreasonable restraint of trade, while leaving all others unaffected by the provisions of the act; that the common law meaning of the term "contract in restraint of trade," includes only such contracts as are in unreasonable restraint of trade, and when that term is used in the Federal statute it is not intended to include all contracts 'in restraint of trade, but only those which are in unreasonable restraint thereof." This is exactly the holding of SANBORN and Thayer, JJ., in the Court of Appeals.

Justice PrCKenam continues: "The term is not of such limited signification, contracts in restraint of trade have been known and spoken of for hundreds of years both in England and in this country, and the term includes all kinds of those contracts which in fact restrain or may restrain trade. Sorme of such contracts have been heid void and unenforceable in the courts by reason of their restraint being unreasonable, while others have been held valid because they were rot of that nature.. A contract may be in restraint of trade and still be valid at common law. Although valid, it is nevertheless a contract in restraint of trade, and would be so described either at common law or elsewhere. By the simple.use of the term 'contract in' restraint of trade,' all contracts of that nature, whether valid or otherwise, would be included, and not alone that kind of contract which. was invalid and unenforceable as being in unreasonable restraint of trade. When, therefore, the body of the act pronounces as illegal every contract or combination in restraint of

27 U. S. v. Trans-Mo. Freight Ass'n (1892), 53 Fed. 440.

${ }_{28}$ U. S. v. Trans-Mo. Freight Ass'n (I893), 58 Fed. 58: 
trade or commerce among the several states, the plain and ordinary meaning of such language is not limited to that kind of contract alone which is in unreasonable restraint of trade, but all contracts are included in such language, and no exception or limitation can be added without placing in the act that which has been omitted by Congress."

In United States v. Joint Traffic Ass'n,'20 the facts were similar and a reconsideration of the holding in the Trans-Missouri case was asked, on the ground that the Anti-trust Act, if it made "every contract in restraint of interstate commerce" illegal, the act was then unconstitútional as depriving persons of their liberty without due process of law. The court, however; overruled this, and reaffirmed the view taken in the Trans-Missouri case. Mr. Justice Picknam again delivered the opinion of the court, and GRAY, SHIRAS, and WHITE, JjJ., dissented.

The same constitutional point was affirmed in Addyston Pipe and Steel Co. v. U. S., ${ }^{30}$ and also in Montague \& Co. v. Lowrie, ${ }^{31} \mathrm{Mr}$. Justice PeCKHAM delivering the opinions in both cases.

In Northern Securities Co. v. U. S., ${ }^{32}$ the question was again raised, Justices HARLAN, BRown, McKENNA and DAY holding that the Anti-trust Act "embraces all direct restraints, reasonable or unreasonable." In his concurring opinion, Mr. Justice BrEWER, however, said of the preceding Traffic Association and other cases, "Instead of holding that the Anti-trust Act included all contracts reasonable or unreasonable, in restraint of interstate trade, the ruling should have been that the contracts there presented were unreasonable restraints of interstate trade, and as such within the scope of the act. *** Congress did not intend to reach and destroy those minor contracts in partial. restraint of trade which the long course of decisions at common law had affirmed were reasonable and ought to be upheld", In this case Fulter, ,C. J., White, PECKHAM, Hórmes, JJ., dissented on the ground that. "the acquisition and ownership of stock in competing railroads, organized under state law, by several persons or by corporations, is not interstate commerce, and, therefore, not subject to the control of Congress." But in Loewe v. Lawlor, ${ }^{33}$ Chief. Justice FULLER speaking for the whole court without dissent, citing the foregoing cases says (p. 297), they "hold in effect that' the Anti-trust law has a broader application than the prohibition of restraints of trade unlawful at common law."

$=$ I7I U. S. 556 .

2 I75 U. S. 228.

21 I93 U. S. 38.

32193 U. S. 197 .

* 208 U. S. 274 . 
The road Chief Justice WHI'te travels in reaching the conclusion that only unreasonable restraint is forbiclden is:

"The text of the first and second sections of the act is:

"Section I. Every contract, combination in the form of trust or otherwise or conspiracy, in restraint of trade or commerce, among the several states, or with foreign nations, is hereby declared to be illegal. ***"

"Section 2. Every person who shall monopolize or attempt to monopolize or combine or conspire with any person or persons to monopolize any part of the trade or commerce among the several. states, or with foreign nations, shall be cleemed guilty of a misdemeanor. ***"

"The debates show that doubt as to whether there was a common law of the United States which governed the subject in the absence of legislation was among the influences leading to the passage of the act. They conclusively show, however, that the main cause which led to the legislation was the thought $* * *$ that combinations known as trusts were being multiplied, and the widespread impression that their power had been and would be exerted to oppress individuals and injure the public generally."

"The sole subject with which the first section deals is restraint of trade, as therein contemplated, and the attempt to monopolize is the subject with which the second section is concerned. It is certain that those terms, at least in their rudimentary meaning, took their origin in the common law and were familiar in the law of this country prior to and at the time of the adoption of the act in question."

"It is certain that at a remote period the words contract in restraint of trade in England came to refer to some voluntary restraint put by contract by an individual on his right to carry on his trade or calling. Originally all such contracts were considered to be illegal, because it was deemed they were injurious to the public as well as to the individuals who made them. In the interest of freedom of individuals to contract this doctrine was modified so that it was only when a restraint by contract was so general as to be coterminous with the kingdom that it was treated as void. That is to say, if the restraint was partial in its operation and was otherwise reasonable the contract was held to be valid."

"Monopolies were defined by Lord Core as follows: 'A monopoly is an institution, or allowance by the king by his grant, com- mission, or otherwise to any person or persons, bodies politic or corporation, of or for the sole buying, selling, making, working, or using of any thing, whereby any person or persons, bodies politic or 
corporate are sought to be restrained of any freedom or liberty that they had before, or hinclered in their lawful trade.' "

"As monopoly, as thus conceived, embraced only a consequent arising from an exertion of sovereign power, no express restrictions or prohibitions obtained against the creation by an inclividual of a monopoly as such."

"But as it was considered, at least so far as. the necessaries of life were concerned, that inclivicluals by the abuse of their right of contract might be able to usurp the power arbitrarily to enhance prices, one of the wrongs arising from monopoly; it came to be that laws were passed relating to offenses such as forestalling and engrossing, by which prohibitions were placed upon the power of inclivicluals to deal under such circumstances and conditions as $* * *$ to give rise to the presumption of an intent to injure others through the means of a monopolistic increase of prices."

Hence, "the prohibited act of engrossing, because of its inevitable accomplishment of one of the evils cléenned to be engendered by monopoly, came to be referred to às being a monopoly or constituting an attempt to monopolize."

"From the development of more accurate economic conceptions and the clianges in conclitions of society it came to be recognized that the acts prohibited by the engrossing, forestalling, etc., statutes did not have the harmful tendency which they were presumed to have when the legislation concerning them was enacted," and so such acts were repealed in England in I844.

"By an early statute of the Province of Massachusetts,1778-1779, monopoly and forestalling were expressly treated as one and the same. It is also true that the principles concerning contracts in restraint of trade, that is voluntary restrainit put by a person on his. right to pursué his calling, came generally to be recognized in accordance with the English rule. It came, moreover to pass that contracts or acts which it was considered had a monopolistic tendency, especially those which were thought to unduly diminish competition and hence to enhance prices-in other words, to monopolize-came also in a generic sense to be spoken of and treated as they had been in England, as restricting the due course of trade, and therefore as being " in restraint of trade."

"Without going into detail and but briefly surveying the whole field, it may be with accuracy, said that the dread of enhancement of prices and of other wrongs which, it was thought, would flow from the undue limitation of competitive conditions caused by contracts or other acts of individuals or corporations, led as a matter of public policy, to the prohibition or treating as illegal of contracts 
or acts which were unreasonably restrictive of competitive conditions, either from the nature or character of the contract or act, or where the surrounding circumstances were such as to justify the conclusion they had not been entered into or performed with the legitimate purpose of reasonably forwarding personal interest and developing trade, but on the contrary were of such a character as to give rise to the inference or presumption that they had been entered into or done with the intent to do wrong to the general public and to limit the right of individuals, thus restraining the free flow of commerce and tending to bring about the evils, such as enhancement. of prices, which were considered to be against public policy."

"In view of the common law and the law in this country as to restraint of trade, which we have reviewed, we,think it results," as to the first section:

"[a]. That the context manifests that the statute was drawn in the light of. the existing practical conception of the law of restraint of trade."

"[b]. That in view of the many new forms of contracts and combinations which were being evolved from existing economic conditions, it was deemed essential by an all embracing enumeration to make sure that no form of contract or combination by which an undue restraint of interstate or foreign commerce was brought about could save such restraint from condemnation."

"[ $[\vec{c}]$. And as the contracts or acts embraced in the provision were not expressly defined, since the enumeration addressed itself to classes broad enough to embrace every conceivable contract or combination which could be made concerning trade or commerce or the subjects of such commerce, and thus caused any act done by any of the enumerated methods anywhere in the whole field of human activity to be illegal if in restraint of trade, it inevitably follows that the provision necessarily called for the exercise of judgment which required that some standard should be resorted to for the purpose of determining whether the prohibitions contained in the statute had or had not in any given case been violated. Thus not specifying, but indubitably contemplating and requiring a standard, it follows that it was intended that the standard of reason which had been applied to the common law and in this country in dealing with subjects of the character embraced by the statute was intended to be the measure used for the purpose of determining whether in a given case a particular act had or had not brought about the wrong, against which the statute provided."

"And a consideration of the text of the second section serves to establish that it was intended to supplement the first and to make 
sure that by. no possible guise could the public policy embodied in the first section be frustrated or evaded if possible, to make the prohibitions of the act all the more complete and perfect by embracing all attempts to reach the end prohibited by the first section; that is, restraints of trade, by any attempt to monopolize or monopolization thereof, even though the acts by which such results are attempted to be brought about or are brought about be not embraced within the general enumeration of the first section.

"And, of course, when the second section is thus harmonized with and made, as it was intended to be, the complement of the first, it becomes obvious that the criteria to be-resorted to in any given case for the purpose of ascertaining whether violations of the section have been committed, is the rule of reason, guided by the established law and by the plain duty to enforce the prohibitions of the act, and thus the public policy which its restrictions were obviously enacted to subserve."

In dissenting from this view Mr. Justice HARLAN says: "There are some things in this opinion, and some that are to result from this opinion, which I think may very well alarm thoughtful men, or many thoughtful men; and I am unwilling to let them pass with any idea that I approve them.

"The anti-trust act of 1890 was passed at a time when this ccuntry was in a state of great unrest, arising out of enormous aggregation of capital-in a few hands, and arising out of combinations which had their hands upon the throat of this country in respect even to the necessities of life; and Congress had before it the great question as to how these evils were to be remedied, so far as Congress had the power to remedy them. The question was: What shall we do? They finally, after great debate by able statesmen, passed the anti-trust act of I89o. It provides in section I, "That every contract, combination in form of trust or otherwise, or conspiracy not in restraint of trade, as the learned chief justice said in one part of his remarks, but $* * *$ in restraint of trade among the several states and with foreign nations is hereby declared to be illegal.'

"Congress has nothing to do with domestic trade in the states, but as to interstate trade it has a great deal to do, and therefore it fell upon this policy.

"The men who were in the Congress of the United States at that time knew what the common law was about the restraint of trade. They knew what restraints of trade at common law were lawful and what were unlawful. But Congress said:

"The surest way to protect interstate commerce is not to start upon any distinctions at all as to the kinds of trade; 'every' contract 
in restraint of trade among the states is hereby declared to be illegal. "Then, in the second section:

" 'Every person who shall monopolize or attempt to monopolize or combine or conspire with any other person or persons to monopolize'-Monopolize what? 'Any part of interstate trade or commerce shall be liable to the penalties prescribed by this act.' What becomes, then, of the statement that this act did not condemn monopoly-in itself? Did not these men know what a monopoly was? And when Congress said that we will punish any man who monofolizes or attempts to monopolize any part of interstate commerce, did it not know what it intended? That is not all: 'Every. contract, combination in form of trust or otherwise, or conspiracy in restraint of trade or commerce among the states, is hereby declared illegal.

"Therefore Congress said to all the people of this country: "We are not going to bother the courts or ourselves with any inquiries as to what contracts are in restraint of trade, reasonably or unreasonably. We are not going to leave that to any jury. We àre not going to leave that to any circuit judge. We will determine it as a part of the policy of the United States, that, so far as interstate trade is concerned, nobody or corporation shall make or attempt to enforce a contract, any contract, that in any degree restrains interstate trade.' Can anybody cloubt the meaning of those words? *** What occurred next? Look at this, step by step, and I shall get directly, to the part of this opinion that I say may well alarm the country, notwithstanding the many good things that are in it, magnificently said.

"In 1896; fifteen years ago, a case was in this court known as the Trans-Missouri case. The question involved the construction as to the scope and meaning of that anti-trust law. Who was here to instruct the court on that occasion? We hear a good deal about the 'lamp of reason.' We hear that the time has come when we should hold up the light of reason and look at this act; as if the men of that day, freshly after the passage of the act, were moving about in darkness and did not know what they were doing or saying.

"Let us see who were the men in the case. They were, Attorney General Harmon, W. F. Guthrie, John F. Dillon, James C. Carter, Edward J.IPhelps, Lloyd W. Bowers, and John G. Jolinson." Justice HarLan thien quotes extensively from this case, including the quotations given above. He also quotes from the Joint Traffic case, showing that that case reaffirmed the Trans-Missouri case after the fullest argument by the same distinguished attorneys with the help of Senator Edmunds, and after the fullest consideration of the same views of Mr. Justice WHITE in his dissenting 
opinion, and.still further, after a rehearing, for a third time the majority of the court held the same. $\mathrm{He}$ adds: "If you will take the trouble to look through the Federal Reporter you will find that possibly nearly every Federal court in this country has accepted those original decisions as the final decision of this court as to the meaning of the act of Congress.

"Now it is laid down in some of the cases, and it is common sense, that this court is bound to know what everybody else in the community knows, and therefore I say, without hesitation, that everybody knows that there has not been a session of Congress since 1896 , when that original opinion was delivered but that somebody, taking the opposite view from what the court has said, has applied to Congress to get that law amencled; but it never has been amended, and there is not a man in the country today who does not know that it never will be amended by the Congress of the United States to mean what they wanted Congress to have it mean, and which Congress refused to have it mean; to get the courts so to construe it.

"In the not very short life that I have passed in this capital and the public service of the country the most alarming tendency of this day, in my judgment, so far as the safety and integrity of our institutions are concerned. is the tendency to judicial legislation, so that, when men having vast interests are concerned and they cannot get the law-making power of the country which controls it to pass the legislation they desire, the next thing they do is to raise the question in some case, to get the court so to construe the Constitution or the statutes as to mean what they want it to mean. That has not been our practice."

Although it is usually said that debates in a legislative bocly may not be resorted to to determine the meaning of a statute, ${ }^{34}$ yet the reports of committees may be.:35 It is, however, proper for the purposes of review to look into the proceedings of Congress.

Section $I$, of the original bill ${ }^{3 i}$ introduced by Senator SHTRMAN read: “That all arrangements, contracts, agreements, trusts, or combinations between persons or corporations made avith a vieci, or which tend, to prevent full and free competition in the importation, transportation, or sale," etc., and "all arrangements, contracts, agreements, trusts, or combinations between persons or corporations designed, or which tend, to advance the cost to the consumer of any such articles, are hereby declared to be against public policy, unlaw-
ful and void."

The Senator said: "It does not announce a new principle of law,

${ }^{34} U$. S. v. Trans-Mrissouri Frt. $\Lambda s s^{\prime n}$, 166.U. S. 318.

35 Church of Holy Trinity v. U. S., 143 U. S. 457 .

so 5 Ist Cong. Ist Sess., Dec. 4, I\$89, Senate Bill No. 1, Bills \& Debates, p. 69. 
but applies old and well recognized principles of the common law to the complicated jurisdiction of our State and Federal Government. Similar contracts in any State in the Union are now by the common or statute law, null and void. *** The purpose of this bill is to enable the courts of the United States to apply the same remedies against combinations which injuriously affect the interests of the United States that have been applied in the several States to protect local interests.

"This Section (I) will enable the Courts of the U. S. to restrain, limit, and control such combinations as interfere injuriously with our foreign and interstate commerce to the same extent that the state courts habitually control such combinations as interfere with the commerce of a State.

"This bill, as I would have it, has for its single object to invoke the aid of the courts of the United States to deal with the combinations described in the first section when they affect injuriously our foreign and interstate commerce and our revenue laws, and in this way to supplement the enforcement of the established rules of the common and statute law by the courts of the several States in dealing with combinations that affect injuriously the industrial liberty of the citizens of these states.

"This bill does not seek to cripple combinations of capital and labor, the formation of partnerships or of corporations, but only to prevent and control combinations made with a view to prevent competition, or for the restraint of trade, or to increase the profits of the producer at the cost of the consumer. It is the unlawful combination, tested by the rules of the common law and human experience, that is aimed at by this bill, and not the lawful and useful combinations."

The bill "does not interfere with any lawful business in the United States, whether conducted by a corporation or a partnership or an individual. It deals only with unlawful combinations, unlawful by the code of any law of any civilized nation of ancient or modern, times."

The Senator further refers to and quotes from the cases referred to below. After the bill was debated for several weeks in the Senate it was, with numerous proposed amendments, referred to the Judiciary Committee composed of many of the distinguished lawyers of the country. ${ }^{37}$ They reported the bill back in its present form by Senator Edmunds. ${ }^{38}$ Senator HOAR of the committee said:

"We have affirmed the old cloctrine of the common law in regard

37 Bills \& Debates, p. 303.

${ }^{35}$ Ib. 306. 
to all interstate and international commercial transactions, and have clothed the United States courts with authotity to enforce that doctrine by injunction. We have put in also a grave penalty."39 And Senator EDMunds said: "We would frame a bill that should be clearly within our Constitutional power, that we should make its definition out of terms that were well known to the law already, and would leave it to the courts in the first instance to say how far they could carry it or its definitions as applicable to each particular case as it might arise." 10

And Senator EDMunds said in reference to monopoly "that we studied it with whatever little ability we had, and the best answer I can make is to read from Webster's Dictionary the definition of the verb 'to monopolize': 'I. To purchase or obtain possession of the zehole of, as a commodity or goods in market, with the view to appropriate or control the exclusive sale of; as to monopolize sugar or tea.' Like the Sugar Trust. One man, if he had capital enough, could do it just as well as two. '2. To engross or obtain by any means the cxclusive right of, especially the right of trading to any place, or within any country or district; as to monopolize the India or Levant trade.' The old definition. *** We thought we had done the right thing in providing, in the very phrase we did, that if one person instead of two, by a combination, if one person alone, as we have heard about the wheat market in Chicago, for instance, did it, it was just as offensive and injurious to the public interests as if - two had combined to do it."11

Senator EDMUNDS' definition of monopoly should be noted, especially the first,-purchase of the whole commodity to control its sale. He, as does the Chief Justice, assumes that the second definition given, is the old one; this is a mistake, it only goes back to Lord Cork; the other, the first one, back to ARISTOTLE,-and literally means a "sole seller." ARISTOTLE says: Thales, the Milesian philosopher, was reproached for his poverty, but "he knew by his skill in the stars while it was yet winter that there would be a great harvest of olives in the coming year; so having a little money, he gave deposits for the use of all the olive-presses in Chios and Miletus, which he hired at a low price because no one bid against him.. When the harvest-time came, and many wanted them all at once and of a sudden, he let them out at any rate he pleased, and made a quantity of money. He is supposed to have given striking proof of his wisdom, but, as I was saying, his device for getting money is nothing but the creation of a monopoly."

\footnotetext{
20 Ib. 3II.

1 Ib. 375 .

11 Ib. p. 324 .
} 
So too, "there was a man of Sicily, who having money deposited with him, bought up all the iron from the iron mines; afterwards, when the merchants from their various markets came to buy, he was the only seller, and without much increasing the price he gained 200 per cent. Which when Dionysius heard, he told him he might take away his money, but that he must not remain in Syracuse. He had the same idea as Thales; they both contrived to create a monopoly for themselves. And statesmen ought to know these things." ${ }_{42}$

The foregoing statements seem to confirm the view of the Chief Justice; this, however, is only apparent, and a careful study of the debates leads to a different view. (I) Senator SHERMAN's original bill was aimed at "all ariangements, contracts, etc., made with a view, or which tend to prevent full and free competition" in interstate and foreign commerce; it made these illegal, null and void. (2) He pointed out that the purchase of property by one person of another, the formation of partnerships or corporations, to aid production, are not combinations which prevent competition in the legal sense,--they are not contracts in restraint of trade within the meaning of the common law. (3) He cited cases: "that all combinations for the purpose of raising or controlling prices of merchandise or any of the necessaries of life are monopolies,"-matches here,- and "it is no answer to say that it has reduced the price," for it can "at. any time raise the price to an exorbitant degree;" ship among the grain dealers in a town,-each firm apparently conducting its own business as if no such partnership existed,- "to control the price of grain, costs of storage and expense of shipment at such town is in restraint of trade, and void ; ${ }^{44}$ the division of the city of Chicago by agreement between two gas companies, "allowing each the exclusive right of supplying gas therein for roo years, and stipulating that neither would interfere with the business of the other in its own territory," although "it involved a partial restraint of trade," was void as between "corporations engaged in a public business in which the public have an interest," 45 and the purchase of a majority of the capital stock of the four competing gas companies in Cliicago, by a new corporation incorporated for "the manufacture, sale and distribution of gas, and to purchase and hold the capital stock of any gas company in Chicago or elsewhere," builds up "a virtual monopoly in the manufacture and sale of gas," which is unlawful and the corporation can be dissolved;" and "any combination the tendency

12 Politics, Bk. I.

43 Richardson v. Buhl (1889), 77 Mich. 632.

4 Craft v. McConoughy (1875), 79 IIl. 346.

45 Chicago Gas L. Co. v. People's Gas L. Co., 121 Ill. 53 r.

to People v. Chicago Gas 'Trust Co. (1889), I30 Ill. 268. 
of which is to prevent competition in its broad and general sense, and thus at will enhance prices to the detriment of the public is a legal monopoly. ${ }^{47}$ (4) These views were not controverted, denied or questioned, but seemed to be taken for granted by all. And further the debates seem to assume, that for practical purposes, any contract "made with the view and directly tending to prevent full and free competition" in interstate commerce, since it would affect the people of at least two states, and might all of them,-would be inherently in unreasonable restraint of trade by the rules of the common law. (5) But the Senator also proposed that the policy of the States not only as indicated by the decisions but by their statutes as well, making these things criminal and tortions, should be supplemented by adopting a like policy by the Federal government in reference to interstate and foreign commerce. (6) The debate was mostly upon the remedies for these wrongs, - should they be made criminal, should they be enjoined at the suit of the United States, should a person not a party to the restraining contract have a civil remedy for the damage done him, or should these things be held null, void and unenforcible, by the parties to them, as at common law? No one proposed the latter alone, but all desired to provide one or more of the other remedies; and this is why the original bill was referred ${ }^{x}$ to the Judiciary Committee, and why it reported the bill in its present form-to extend the policy of the states to interstate and foreign commerce,-to make violations thereof criminal, clothe the Federal courts with power to enforce this policy by injunction, and give a civil remedy to a person injured by its violation. (7) So too, because the bill said nothing about monopoly, and would not prevent cornering the market, 'was another objection to it; hence the judiciary committee added the monopoly section. If this is correct, then it seems probable that 'every contract,' was deliberately used to mean what it says; and this seems to be more than confirmed by the subsequent history set forth in Justice HARIAN's opinion.

It is not quite clear therefore why the court should in.a case not requiring it, and when the question was touched upon only incidently in the briefs,--because it had been considered practically settled for fifteen years, suddenly reverse itself, and mount that "unruly horse"public policy-which no court has ever yet successfully ridden and which will vary as it has heretofore, in matters of this kind, on the equity side "with the length of the chancellor's foot," and on the legal side from Hull's "per Dieu, if the plaintiff were here, he should go to prison till he paid a fine to the King," because he took a bond

IT Mr. Justice Barrett, in People v. North River Sugar Ref. Có., a Abb. ‥ C. 164. 
from a dyer not to "use his dyer's craft in town for half a year, ${ }^{48}$ to the House of Lords' conclusion that a combination to engross all the tea trade between Shanghai and Europe, to the exclusion of the plaintiff, was not unlawful,- - so as to give the plaintiff an action for damages $;^{40}$ the court here, however, was careful to point out that while this was a contract in restraint of tradc, it was not unlawful, so as to give a third party an action for damages; they did not hold that it was a contract in "reasonable restraint of trade," so that one party to it would have had an action against another for damages for refusing to abide by it; they probably would have refused to enforce it so, because it was in unrcasonable restraint of trade. ${ }^{50}$ And it is safe to say that had the case arisen before 1844 , the court would hardly have held under the laissez faire rule of reason so. fashionable at the time that the English statutes did not apply as they before had been interpreted. It would have been left to Parliament, as it was, to abrogate the statutes and establish a new policy.

However, if hereafter, the common law rule of reason is to apply, and though this will lead to a sea of uncertainty, if one can judge by the conflict in the views of the members of the court, perhaps the ultimate result will not be greatly different, except to throw a greater burden on the government in getting at and establishing the facts in each case. There is not much in the common law rule of reason, except its uncertainty, to give comfort to any of the large trusts to classify themselves among the sheep insteacl of among the goats. The best statement of the common law, so far as it can be stated at all, is that made by President TAFT, when as judge he rendered the decision in the Addyston Pipe, Case. ${ }^{51}$ He said, citing cases in the note: "Covenants in partial restraint of trade are generally upheld as valid when they are agreements; (I) by the seller of property or business not to compete with the buyer in such a way as to derogate from the value of property or business sold; (2) by a retiring partner not to compete with the firm; (3) by a partner, pending the partnership, not to do anything to interfere, by competition or otherwise, with the business of the firm; (4) by the buyer of property not to use the same in competition with the business retained by the seller; and (5) by an assistant, servant or agent not to compete with his master or employer after the expiration of his time of service. Before such agreements are upheld, however, the court must find that the restraints attempted thereby are reasonably necessary ( $\mathrm{I}, 2$ and 3 ) to the enjoyment by the buyer of the property, good-will or in-

18 Dier's Case (1415), Y. I. 2 II. V. f. 5, pl. 26.

10 Mogul Steamship Co. v. McGregor [1892], A. C. 25.

30 Nordenfelt v. Maxim \&.c. Co. [1894], A. C. 535 .

51 United States v. Aldyston \&c. Co. (1898), 85 Fed. 27 r. 
terest in the partnership bought; or (4) to the legitimate ends of the existing partnership; or (5) to the prevention of possible injury to the business of the seller from use by the buyer of the thing sold; or (6) to protection from the danger of loss to the employer's business caused by the unjust use on the part of the employe of the confidential knowledge acquired in such business.52 But where the sole object of both parties in making the contract as expressed therein is merely to restrain competition, and enhance or maintain prices, it would seem that there was nothing to justify or excuse the restraint, that it would necessarily have a tendency to monopoly and therefore would be void. In such a case there is. no measure of what is necessary to the protection of either party except the vague and varying opinion of judges as to how much, on principles of political economy, men ought to be allowed to restrain competition. There is in such contracts no main lawful purpose to subserve which partial restraint is permitted, and by which its reasonableness is measured, but the sole object is to restrain trade in order to avoid the competition which it has always been the policy of the common law to foster."

52 First class: Mitchel v. Reynolds, I P. Wms. I8I; Fowle v. Parke, 13I U. S. 88, g Sup. Ct. 658; Nordenfelt v. Maxim-Nordenfelt Co. [1894], App. Cas. 534; Rousillon v. Rousillon, 14 Ch. Div. 351 ; Cloth Co. v. Lorsont, L. R. 9 Eq. 345; Whittaker v. Howe, 3 Beav. 383 ; Match Co. v. Roeber, ro6 N. Y. 473, I3 N. E. 419; Tode v. Gross. 127 N. Y. 480.28 N. E. 469 ; Beal v. Chase, 32 Mich. 490 ; Hubbard v. Miller, 27 Mich. 15; National Ben. Co. v. Union Hospital Co., 45 Minn. 272, 47 N. W. Rep. 806; Whitney v. Slayton, 40 Maine 224; Pierce v. Fuller, 8 Mass. 223; Richards v. Seating Co., 87 Wis. 503,58 N. W. Rẹp. 787.

Second class: Tallis v. Tállis, I El. \& Bl. 39r, and Lange v. Werk, 2 Ohio St. 520.

Third class: Machinery Co. v. Dolph, 138 U. S. 617, II Sup. Ct. 412; Machinery Co. v. Dolph, 28 Fed. Rep. 553; and Matthews v. Associated Press, 136 N. Y. 333, 32 N. E. Rep. 981 .

Fourth class: American Strawboard Co. v. Haldeman Paper Co., 83 Fed. Rep. 6rg; and Hitchcock v. Anthony, 83 Fed. Rep. 779. . both decisions of this court; Navigation Co. v. Winsor, 20 Wall. 64; Dunlop v. Gregory, 1o N. Y. 24I; Ilodge v. Sloan, 107 N. Y. 244,17 N. I. Rep. 335 .

Fifth class: Homer v. Ashford, 3 Bing. 322; Horner v. Graves, 7 Bing. 735; Hitchcock v. Coker, 6 Adol. \& E. 438; Ward v. Byrne, 5 Mees. \& W. 547; Dubowski v. Goldstein (1896), I Q. B. 478; Peels v. Saalfeld (1892), 2 Ch. 149; Taylor v. Blanchard, I3 Allen 370; Keeler v. Taylor, 53 Pa. St. 467; Herreshoff v. Boutineau, 17 R. I. 3. 19 Atl. Rep. 712 .

witing: I'eople v. Sheldon, 139 N. Y. 25r; Morris Run Coal Co. v. Barclay Coal Co., $68 \mathrm{~Pa}$. St. 173; Nester v. Brewing Co., 161 Pa. St. 473; Salt Co. v. Guthrie, 35 O. S. 666; Anderson v. Jett, 89 Ky. 375; Chapin v. Brown, 79 Ill. 346; Craft v. McConoughy, 79 Ill. 346; More v. IBennett. 140 Ill. 69; Association v. Niezerowski, 95 Wis. 129 ; Vulcan Powder Co. v. Hercules Powder Co., 96 Cal. 510 ; Oil Co. v. Adone, 83 Tex. 650; Association v. Kock. I4 La. Ann. I68; Hilton v. Eckersley, 6 1jl. \& Bl. 47 ; Urmston v. Whitelegg, 63 L. T. (N. S.) 455.

See also Ilartman v. Park \& Sons, 145 Fed. 358; Page, Contracts, 873 ; Ripley, Trusts, Pools \& Corporations, Chs. IX. X. 8 Mich. L. Rev. 298 (J. C. Knowiton): 6 Mich. L. Rer. I (S. T. Miller); 3 Mich. L. Rev. I19 (D. M. Firedericksen). 
And in the very recent case of Dr. Miles Med. Co. v. John D. Park Sons Co., ${ }^{54} \mathrm{Mr}$. Justice Hughes says: "But agreements or combinations between dealers, having for their sole purpose the destruction of competition and the fixing of prices, are injurious to the public interest and void. They are not saved by the advantages which the participants expect to derive from the enhanced price to the consumer."

The decisions of the Supreme Court under the anti-trust act may be summarized and classified as follows: (I) Purchase or acquisition of stock of competing corporations by one of the competitors for the purpose of preventing competition or creating a monopoly.

Of this class are the Sugar Trust cases. In the Knight case,55 the American Sugar Refinery Company, being in control of a large part of the manufactories of refined sugar in the United. States, purchased all the stock of four competing Philadelphia sugar refineries, giving the American Co a practical monopoly of the refining and sale of sugar in the United States; it was held, by FULLER, C. J., that "conceding the existence of a monopoly in the manufacture is established," it cannot be suppressed in the mode attempted in this bill, because manufacturing is not commerce. HARLAN, J., dissents.

In the Kissel case, ${ }^{50}$ the same American Sugar Refining Co., by Kissel, its agent, without disclosing his principal, loaned a large sum of mioney to $\mathrm{S}$. (who owned more than half the stock of a competing Pennsylvania Co.), and took this stock, with a power of attorney to vote upon it, as collateral security for the loan, which was to last for one year. S. did not know the American Co. was back of $K$., and was dependent upon the income of this stock to repay the loan. K., at the instigation of the American Co., voted to close the Pennsylvania Co., and thereby destroy its business, and ruin S. Held, this was an illegal conspiracy, violating the Anti-trust act,- "a partnership for a criminal purpose,"-per HoLmEs, J., no dissent.

Perhaps in this class should also be placed the Northern Securities case, and the case under review. See No. (3) below.

(2) Purchase or lease of competing properties with covenant from the seller or lessor that he will not compete with the purchaser.

In the Packct case, ${ }^{5 \pi}$ a seller of two river steamboats plying between two places and the intermediate points in the State of Olio on the Ohio river, agreed not to engage in the packet business for

us (r911), 3I S. C. 376 on 385 .

$\approx$ U. S. v. F. C. Knight Co. (1895), it6 U. S. I; 60 Fèl. 934.

ca U. S. v. Kissel (1910), - U. S. - 31' 'S. C. 124; 173 Fed. 823.

st Cincinnati, I. I. \&c. Packet Co. v. Bay'(1906), 200 U. S. I79. 
five years between the same points, -held, HoLmes, J., even if there is some interference with interstate commerce, it "is insignificant, and inciclental and not the dominant purpose of the agreement" which relates to intrastate traffic only, and does not violate the Anti-trust act. No dissent.

In the Cotton Compress case, .8 the lessee already owned and controlled a large number of the cotton compresses in the southern states; the lessor compress company leased all its property and good will to the foreign lessee company, with a covenant to discourage all competition with the latter, and itself refrain from engaging in compressing cotton within 50 miles of any plant operated by the lessee,this lease being made in pursuance of a plan to draw into one control the compression business of the cotton producing states. Held, McKenNa, J., violates Anti-trust act. No dissent.

The Banana trust, noted below (7), was of this character also.

(3) Organization of a trust or corporation by former competing concerns, or by their shareholders, to take over the property or stock of such concerns in order to prevent competition.

Of this class is the Northern Securities case,, 50 . where the Securities Company was organized with $\$ 400,000,000$ of capital stock, $\$ 2$ II,000,000 of which it exchanged with the stocklholders of the Great Northern Railroad Co., for practically' all of its $\$ 118,000,000$ capital stock, and likewise exchanged $\$ 177,000,000$ more of its stock with the shareholders of the Northern Pacific Railroad Co., for practically all of its $\$ 154,000,000$ capital stock, -giving the former shareholders about $\$ 388,000,000$ of the. Securities' stock, while the latter company became the sole shareholder in the two railroad companies, with power to control them and prevent the continuance of competition between their 5500 miles of lines. Held, HARLAN, Brown, IMcKenna, DAy, and Brewer, that this violated the Antitrust act, Furler, C. J., PECKHAM, Holmes, and White, JJ., dissenting on the ground that exchange of shares was purchase of property, and not a combination or contract in restraint of interstate commerce. Compare the Sugar trust cases, supra, under (I)

In the subsequent case, ${ }^{60}$ arising out of the distribution of the assets of the Securities Co., under the decree in the original case, it was held that there was a real purchase of the stock of the railroad companies by the Securities Co., -and the $\$ 1$ I8,000,000 stock of Great Northern, and \$I54,000;000 stock of Northern Pacific should not be returned to the original owners respectively from

\footnotetext{
s8 Shawnee Compress Co. v. Anderson (1908), 209 U. S. 423, 28 S. C. 572.

B2 U. S. v. Northern Securities Co. (rg04), 193 U. S. 197; 120 Fed. 721. Fed. 464 .

o Harriman v. Northern Securities Co. (I905), I97 U. S. 244; I34 Fęd. 331, I32
} 
whom they were received, but that the two stocks should be divided pro-rata, among all the shareholders in the Securities company who should surrender 99 per cent. of the Securities stock, - opinion by FulLER, C. J. No dissent.

The case under review belongs to this class.

(4) Agreements to fix or maintain transportation rates on interstate traffic.

The cases here are the freight association cases, ${ }^{61}$ sufficiently reviewed above. The Securities case belongs here too, because the majority of the court held that even if there was a sale and purchase of property, that would not purge the plain intent to restrain competition between competing railroads.

In the Packet case, supra, where-the purchaser of the steamboats agreed to maintain the present rates,- primarily at least on intrastate traffic, there was no violation of the Anti-trust act.

(5) Associations or agreements between former competitors not to compete,-yet otherwise retaining control over their own business.

The Live Stock exchanges at Kansas City, where the State line runs through the stock yards were held not to violate the Anti-trust act. In the Hopkins case, ${ }^{62}$ an association was formed among those whose business it was to receive consignments of live stock from various states, make advances to their owners, feed and care for the stock, prepare them for sale, and sell them on commission, remitting to the owners the balance after deducting costs, expenses, and commissions; they fixed uniform commissions, and agreed to deal with no one who violated rules relating to employment of agents and sending prepaid telegrams. Held, their business was not interstate commerce,-PECKHAM, J., (HARLAN, J., dissenting).

In the Anderson case, ${ }^{63}$ the yard live stock traders, who themselves bought and sold live stock at the Kansas City stock yards, associated together, and agreed not to recognize any one not a member as a yard trader, or employ any one to buy or sell for him unless he had a certificate from the exchange, or pay any buyer or seller any fee for buying or selling for him. Held, such agreement was not in restraint of, nor an attempt to monopolize, interstate commerce, even if its members are engaged in such commerce:

In the Pipe Trust cases, ${ }^{84}$ it was held that an agreement among a large number of the companies manufacturing iron pipe in the United States, fixing prices to the public by a committee, dividing

or U. S. v. Trans-Mo. Frt. Ass'n (1897), 166 U. S. 290; 58 Fed. 58; 53 Fed. 440; U. S. v. Joint Traffic Ass'n (1898), I7I U S. 505; 89 Fed. 1020, 76 Fed. 895 .

oz Hopkins v. U. S. (1898), 171 U. S. 578; 84 Fed. rox8, 82 Fed. 529 .

a Anderson v. U. S. (1898), 17 U. S. $604 ; 82$ Fed. 998.

4h Addyston Pipe \& Steel Co. v. U. S. (1899), 175 U. S. 21 I; 85 Fed. 27r, 78 Fed. 712. 
territory, and pooling profits, violates the Anti-trust act,-per PECKHAM, J: No dissent. The same combination was likewise held to be illegal in the Chattanooga Foundry Works case, ${ }^{05}$ by Holimis, J., two of the court dissenting on other matters.

In the Meat Trust case, ${ }^{\circ C}$ it was held that a combination of the dominating members of dealers in fresh meats throughout the United States to bid in conjunction with and not against one another for live stock, in order to regulate prices, to restrict shipments, and to get less than lawful rates from railroads, violates the Anti-trust act,-Hormes, J. No dissent.

The Packet case is given above under (2).

The Wall Paper trust, ${ }^{\text {"7 }}$ by organizing a selling corporation to fix and maintain prices for its members and limit production, was assumed to be illegal. See below under (6). So too, the Banana trust. See below under (7).

(6) Agreements between seller and buyer that the latter will resell to public only on terms named by the original seller.

Thus where the patentee of harrows sold the right to manufacture and sell the same, to a licensee, and agreed to license no one else, and the licensee agreer to make and sell the harrows at a price fixed by patentee, and to sell no others; the agreement does not violate the Anti-trust act,- ${ }^{\circ}$ PECKram, J. No dissent.

But where the wholesale dealers in tiles, etc., in one state, associate with the makers of such tiles in other states, whereby the makers agree not to sell to non-members and the wholesale dealers agree not to purchase from non-members, and not to sell at all at less than the list prices agreed upon, to non-members,-more than $50 \%$ higher than to members, is an association which violates the act,- ${ }^{\circ \theta}$ per Peckham, J. No dissent.

However, a contract between. a board of trade and a telegraph company, whereby the board agrees to furnish quotations of the prices of grain, on condition that the telegraph company will communicate such prices only to persons having contractual relations with and approved by the board of trade, and not to bucket shops, does not violate the Anti-trust act, ${ }^{70}$ as a contract in restraint of trade,-per Holmes, J. (HARLAN, BREWER, and DAY, JJ., dissenting).

as Chattanooga F. \& P, Works v. Atlanta (1906), 203 U. S. 390,27 S. C. 65.

$\propto$ Swift v. U. S. (1905), I96 U. S. 375; 122 Fed. 529.

or Continental Wall Paper Co. v. Voight (1909), 212 U. S. 227,29 S. C. $280 ; 148$ Fed. 939 .

as Bement v. National Harrow Co. (I902), I86 U. S. 70.

es Montague \& Co. v. Lowry (1904), 193 U. S. 38; I15 Fed. 27, 106 Fed. 38, 98 Fed. $8 x \%$. 608.

70 Board of Trade v. Christie \&c. Co. (1905), 198 U. S. 236; I39 Fed. 496. 121 Fed. 
In the Wall Papor trust, in addition to what is stated above (5) the selling agency fixed prices to wholesalers, to retailers, and to the public, and required the wholesalers to agree to sell to retailers only on the terms' fixed, and the retailers to sell only to the public at the prices fixed by the seller. - Hcld, per HarLAN, J., to violate Antitrust act (HoLMES, BREWER and WIITTE, JJ., dissent on the ground that a wholesale dealer who had purchased a bill of goods from the trust was not in a position to contest the validity of its existence).

The same sort of an agreement whereby the maker and seller of a proprietary medicine made under a secret process undertook to fix the prices to wholesalers, and by them to the retailers, and by the latter to the public, and that such wholesalers should sell only to such retailers as were approved by the proprietor violates the Anti-trust act ; $^{71}$ opinion by Hughes, J. (HoL MEs, J., dissenting).

So too, in Bobbs-Mcrill Co. v. Straus, ${ }^{72}$ the district court held that Bobbs-Merrill Co. could not prevent the sale below a specified price, of a copyrighted book by the purchaser,- -the Book trust, composed of the American Publishers' Ass'n, and the Am. Booksellers' Ass'n, a combination controlling the sale and fixing the price of 90 per cent of the copyrighted books, ar-1 blacklisting dealers who would not come into the association,-even though it was an unlawful trust, as held by the court. This was affirmed, as a restraint on alicnation, the copyright of a book not giving the same right as a patent of an article, but the Supreme Court did not deem it necessary to pass on the validity of the Book trust.

(7) Combinations to prevent others from carrying on their trade in the usual way.

By 'force, threats, violence, and actual physical obstruction, preventing the movement of sleeping cars engaged in interstate.com-

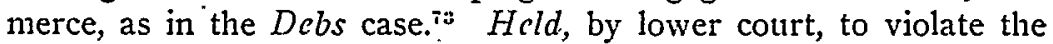
Anti-trust act, but affirmed by the Supreme Court, on broader grounds as interfering with the movement of the mails, etc,-per Brewer, J. No dissent.

So too, a boycott by the hatters union of gooo members, in com. bination with the American Federation of Labor of $1,400,000$ members, of the manufacturer of hats to be transported and sold across state lines whose shop the Union seeks to unionize, by preventing purchasers from reselling for fear of strikes, and loss of customers, because of the wide publication in the Union papers of the names

7 Dr. Miles Med. Co. v. Park \& Sons Co. (1911), - U. S. - 3I S. C. 376; 164 Fed. 803; See Hartman v. John I). Park, 145 Fed. 358.

7210 U. S. 339,28 S. C. $722 ; 147$ Fed. $15 ; 139$ Fed. $155 ; 131$ Fed. 530.

73 In re Debs $(1895), 158$ U. S. $5 G_{4} ; 64$ Fed. 724 . 
of unfair dealers, is a combination in restraint of interstate commerce, in violation of the Anti-trust act, ${ }^{7} \pm$ per FuLLER, C. J. No dissent. :

In the Banana trust case, ${ }^{i 5}$ the trust organized in the United States, with an intent to control competition and monopolize the banana trade, bought out many competitors, who promised not to compete, acquired the stock of others, contracted with still others liniting the quantity to be purchased, and organized a selling corporation to fix and maintain prices. Plaintiff, a United States citizen, acquired a banana plantation in U. S. of Columbia, and proceeded to construct a railroad to it. The trust induced the Costa Rica government to prevent by its soldiers, the plaintiff from completing his road, procured a fraudulent judgment as to the title to the land, and forcibly ejected plaintiff, and destroyed his business. Held, although the parties were engaged in the foreign banana trade of the United States, the wrongful acts occurred outside the territory of the United States, and the Federal courts had no jurisdiction to give relief,per HoLmes, J., all concur.

(8) Miscellaneous.

A municipal ordinance specifying that Trinidad Lake asphalt, a foreign product, shall be used in the pavement of a city street, and thereby preventing competitive bidding does not violate the Antitrust act, ${ }^{-i 0}$ per DAy, $J$. No dissent. Corporations are not protected under the provisions of the 5 th amendment of the Constitution from having their agents testify or their books produced, in a criminal prosecution against them under the Anti-trust act, on the ground that a criminal cannot be required to testify against himself; this privilege is personal to the witness called on to testify. Such corporations, however, are protected against unreasonable searches and seizures. ${ }^{77}$

The facts show that the defendant in the case under review, has been a party to contracts or combinations held illegal under most of the foregoing classes, but particularly of forming a trust or combination, under (3), above, and thereby, and by unlawful agreements with transportation companies, secured illegal preferences, practically as efficient as a special grant from the government would be; they have been, and have intended to be parties to combinations in restraint of interstate commerce, and have attempted to monop-

\footnotetext{
74 Loewe v. Lawlor (x907), 208 U. S. 274,28 S. C. 301 ; 142 Fed. 216 , I30 IFed. 633.

${ }^{75}$ American Banana Co. v. United Fruit Co. (1909), 213 U. S. 347,29 S. C. $511 ; 166$

7o Field v. Barber Asphalt Co. (1904), 194 U. S. 618; Ir7 Fied. 925.

7 Hale v. Henkel (1906), 201 U. S. 43; McAlister v. Henkel, 201 U. S. 99 ; Nelson v. U. S. (1906), 201 U. S. 92 ; Alexander v. U. S. (1906), 201 U. S. II7.
} Fed. $26 x$. 
olize, and have monopolized, such trade and commerce. And in this way they have

“*** Engrossed and píled up

The cankered heaps of strange achieved gold."

There is not much in the common law rule of reason, nor in the cases reviewed, to furnish much of aid or comfort to such existing institutions as are similar to those that have been challenged in the courts heretofore.

UNIUERSITY OF MICHigan.

H. L. WIIGUS: 